\title{
Progression of oral carcinomas revealed by spectral reordering of a bipartite graph
}

\author{
Gabriela Kalna*1, Johanna Thurlow², Keith Vass ${ }^{2}$ and Des Higham ${ }^{1}$
}

Address: ${ }^{1}$ Department of Mathematics, University of Strathclyde, Glasgow G1 1XH, Scotland, UK and ${ }^{2}$ The Beatson Institute for Cancer Research, Glasgow G61 1BD, Scotland, UK

Email: Gabriela Kalna* - gabriela.kalna@strath.ac.uk

* Corresponding author

from BioSysBio 2007: Systems Biology, Bioinformatics and Synthetic Biology

Manchester, UK. II-13 January 2007

Published: 8 May 2007

BMC Systems Biology 2007, I(SuppI I):PI2 doi:I0.II86/I752-0509-I-SI-PI2

This abstract is available from: http://www.biomedcentral.com/I752-0509/I?issue=SI

(C) 2007 Kalna et al; licensee BioMed Central Ltd.

\section{Introduction}

Spectral, singular value decomposition-based, algorithms for dimension reduction and clustering are known to be useful in a range of areas of science and engineering. Motivation for this work is in the analysis of microarray data from a number of different samples leading to a natural bipartite graph framework. Spectral bi-partitioning of microarray data was for the first time considered in [1]. In this work we generalise the ideas in [2] in order to present further theoretical support and investigate a multiclass dataset with the aim of revealing a complex picture of oral cancer progression.

\section{Materials and methods}

A simple and informative derivation of a spectral algorithm for reordering a weighted bipartite graph is presented. We start with a discrete optimization problem then add constraints and relax it into a tractable continuous analogue. Natural data preprocessing is a part of the algorithm. Singular vectors can be used not only for gene/ sample reordering but also for identifying informative genes. The data set pertains to the gene expression profile of different cell cultures (samples) isolated from normal oral tissue $(\mathrm{N})$ and biopsies from different stages of oral cancer: dysplasias (D), primary (P), metastasised (M) and recurrencent cancers (R).

\section{Results}

Currently oral cancer is seen as a single progression mechanism. Here, the bi-partitioning algorithm applied to the gene expression matrix revealed a major distinction (V2 in Figure 1) between mortal and immortal (empty and full symbols) samples suggesting that oral cancer can develop

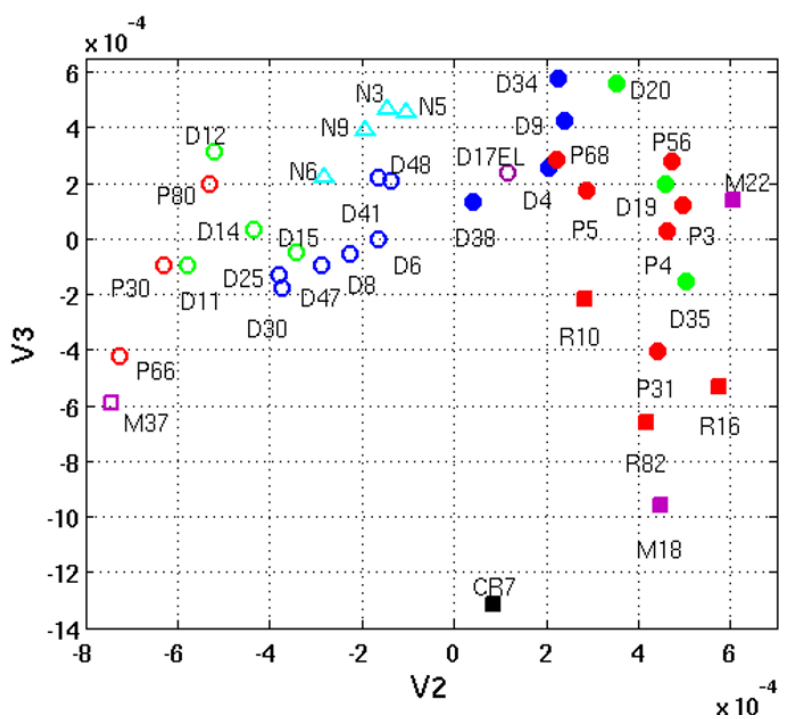

Figure I

Oral cancer: spectral analysis 
by two pathways. Moreover, those dysplasias that are known to have progressed to cancer (green symbols) closely resemble cancer samples. This is of note since currently clinicians lack diagnostic tools to predict which dysplasias are likely to develop into cancer. The algorithm also identifies atypical cultures: a) the extended-lifespan D17EL dysplasia lacks expression of p16 ${ }^{\text {INK4A }} \mathrm{b}$ ) whereas the immortal dysplasia D38 continues to express p $16^{\text {INK4A }}, \mathrm{c}$ ) the immortal cancer P68 that clustered closest to the immortal dysplasias retains wild-type p53. More details can be found in [3].

\section{Conclusion}

Immortality is a dominant factor influencing the overall gene expression profiles of both cancers and dysplasias and outcome data related to the different carcinoma cultures indicates that immortality is associated with poorer prognosis. Analysis of an additional data set shows gene expression changes consistently associated with immortality can be identified in vivo as well as in vitro.

\section{References}

I. Kluger Y, Basri R, Chang JT, Gerstein M: Spectral biclustering of microarray data: coclustering genes and conditions. Genome Res 2003, 13:703-716.

2. Higham DJ, Kalna G, Kibble M: Spectral clustering and its use in bioinformatics. J Comput Appl Math . online 2 June 2006.

3. Hunter KD, Thurlow JK, Fleming J, Drake PJH, Vass JK, Kalna G, Higham DJ, Herzyk P, MacDonald DG, Parkinson EK, Harrison PR: Divergent routes to oral cancer. Cancer Res 2006, 66:7405-74I3.
Publish with Biomed Central and every scientist can read your work free of charge

"BioMed Central will be the most significant development for disseminating the results of biomedical research in our lifetime. " Sir Paul Nurse, Cancer Research UK

Your research papers will be:

- available free of charge to the entire biomedical community

- peer reviewed and published immediately upon acceptance

- cited in PubMed and archived on PubMed Central

- yours - you keep the copyright

Submit your manuscript here:

http://www.biomedcentral.com/info/publishing_adv.asp 